\title{
Determination of Anion Transference Number and Phosphoric Acid Diffusion Coefficient in High Temperature Polymer Electrolyte Membranes
}

Becker, Hans; Reimer, Uwe; Aili, David; Cleemann, Lars N.; Jensen, Jens Oluf; Lehnert, Werner; Li, Qingfeng

Published in:

Journal of the Electrochemical Society

Link to article, DOI:

10.1149/2.1201810jes

Publication date:

2018

Document Version

Publisher's PDF, also known as Version of record

Link back to DTU Orbit

Citation (APA):

Becker, H., Reimer, U., Aili, D., Cleemann, L. N., Jensen, J. O., Lehnert, W., \& Li, Q. (2018). Determination of Anion Transference Number and Phosphoric Acid Diffusion Coefficient in High Temperature Polymer Electrolyte Membranes. Journal of the Electrochemical Society, 165(10), F863-F869. https://doi.org/10.1149/2.1201810jes

\section{General rights}

Copyright and moral rights for the publications made accessible in the public portal are retained by the authors and/or other copyright owners and it is a condition of accessing publications that users recognise and abide by the legal requirements associated with these rights.

- Users may download and print one copy of any publication from the public portal for the purpose of private study or research.

- You may not further distribute the material or use it for any profit-making activity or commercial gain

- You may freely distribute the URL identifying the publication in the public portal 


\title{
ECSS \\ Determination of Anion Transference Number and Phosphoric Acid Diffusion Coefficient in High Temperature Polymer Electrolyte Membranes
}

\author{
Hans Becker, ${ }^{1}$ Uwe Reimer, $\oplus^{2, z}$ David Aili, $\oplus^{1}{ }^{1}$ Lars N. Cleemann, ${ }^{1}{ }^{1}$ Jens Oluf Jensen, $\left({ }^{1, *}\right.$ \\ Werner Lehnert, ${ }^{2,3}$ and Qingfeng $\mathrm{Li} \mathbb{1}^{1, *, \mathrm{z}}$ \\ ${ }^{1}$ Department of Energy Conversion and Storage, Technical University of Denmark, 2800 Kgs. Lyngby, Denmark \\ ${ }^{2}$ Forschungszentrum Jülich, IEK3: Electrochemical Process Engineering, 52425 Jülich, Germany \\ ${ }^{3}$ Modeling in Electrochemical Process Engineering, RWTH Aachen University, Aachen, Germany
}

\begin{abstract}
The passage of an electrical current through phosphoric acid doped polymer membranes involves parasitic migration of the acid, which imposes a critical issue for long-term operation of the high temperature polymer electrolyte membranes fuel cell (HT-PEMFC). To elucidate the phenomenon, a three-layered membrane is constructed with embedded micro reference electrodes to measure phosphoric acid redistribution in a polybenzimidazole based membrane. Under a constant load, a concentration gradient develops due to the acid migration, which drives the back diffusion of the acid and eventually reaches a steady state between migration and diffusion. The acid gradient is measured as a difference in local ohmic resistances of the anode- and cathode-layer membranes by electrochemical impedance spectroscopy. The phosphoric acid diffusion coefficient through the acid doped membrane is about $10^{-11} \mathrm{~m}^{2} \mathrm{~s}^{-1}$, at least one order of magnitude lower than that of aqueous phosphoric acid solutions. The anion $\left(\mathrm{H}_{2} \mathrm{PO}_{4}{ }^{-}\right)$transference number is found to range up to $4 \%$ depending on current density, temperature and atmospheric humidity of the cell, implying that careful control of the operating parameters is needed in order to suppress the vehicular proton conduction as a degradation mitigation strategy.

(C) The Author(s) 2018. Published by ECS. This is an open access article distributed under the terms of the Creative Commons Attribution 4.0 License (CC BY, http://creativecommons.org/licenses/by/4.0/), which permits unrestricted reuse of the work in any medium, provided the original work is properly cited. [DOI: $10.1149 / 2.1201810 \mathrm{jes}$ ]

(cc) BY
\end{abstract}

Manuscript submitted June 8, 2018; revised manuscript received July 17, 2018. Published July 31, 2018.

The high temperature polymer electrolyte membrane fuel cells (HT-PEMFC) typically operate at $140^{\circ} \mathrm{C}-200^{\circ} \mathrm{C}$, which allows for high tolerance against fuel impurities e.g. carbon monoxide and low auxiliary unit complexity on the system level. ${ }^{1}$ The technology has been intensively developed during the last decades, ${ }^{2}$ and degradation rates as low as $0.5 \mu \mathrm{V} \mathrm{h}^{-1}$ have recently been reported under continuous operation for more than $9000 \mathrm{~h}^{3}$

Technically, the cells are constructed around a phosphoric acid doped polymer membrane, in which the ionic conduction is mediated by the phosphoric acid. ${ }^{4}$ The first membranes of this type were based on polybenzimidazoles, e.g. poly (2,2'-(m-phenylene)5,5'-bibenzimidazole) $(m$-PBI), which remains the most widely used material today. ${ }^{5-7}$ A large excess of acid is needed to support ionic conductivity in a practically useful range. At acid doping levels (ADL) of $30-40 \mathrm{H}_{3} \mathrm{PO}_{4}$ per polymer repeat unit the conductivity can reach as high as $0.25 \mathrm{~S} \mathrm{~cm}^{-1}$ at $180^{\circ} \mathrm{C}^{8}$ Practically, an ADL of $10-20$ is a suitable compromise between conductivity on one hand and mechanical robustness on the other.

The chemistry of this class of electrolyte systems is highly complex, as they are composed of species from dissociation and condensation of phosphoric acid, such as pyrophosphoric and polyphosphoric acid of different degrees of hydration, ${ }^{9}$ together with water and the structural base polymer. ${ }^{10}$ The understanding is further complicated by the compositional changes that follows when the conditions, e.g. temperature and humidity, change.

Although phosphoric acid based electrolytes have been extensively used for a long time, the underlying mechanisms behind the high intrinsic ionic conductivity have remained unclear until recently. As reported by Vilčiauskas et al., ${ }^{11}$ the high intrinsic conductivity is connected to the imbalance between the numbers of proton donors and acceptors. This induces a high degree of proton "frustration", and with a low activation energy of typically $2 \mathrm{kcal} \mathrm{mol}^{-1}$, protons are conducted by rapid intermolecular proton transfer via hydrogen bond forming and breaking. ${ }^{12,13}$ This process is commonly referred to as structure diffusion or Grotthuss type proton conductivity, and has for a long time been described as responsible for about $97 \%$

*Electrochemical Society Member.

${ }^{\text {zE} E-m a i l: ~ u . r e i m e r @ f z-j u e l i c h . d e ; ~ q f l i @ d t u . d k ~}$ of the total proton conductivity in phosphoric acid. ${ }^{14}$ The remaining $3 \%$ are attributed to the vehicular mechanism where ionic charges are carried by the acid and water molecules in form of e.g. $\mathrm{H}_{2} \mathrm{PO}_{4}{ }^{-}$ and $\mathrm{H}_{3} \mathrm{O}^{+}$. This is further supported by the negligible electroosmotic water drag coefficient in the acid doped PBI membrane, ${ }^{15}$ although this may also be explained by the fast water diffusion through the membrane. ${ }^{16,17}$

From a technological point of view, the high degree of structure diffusion mechanism is an important asset. Any contribution from vehicular proton transport would introduce parasitic mass transport and the acid balance would have to be maintained by back diffusion. Recent findings show, however, that the structure diffusion mechanism of the proton conductivity in pure phosphoric acid only prevails in a very narrow composition and temperature range. ${ }^{18}$ Indeed, the cation transference number $\left(\mathrm{t}_{\mathrm{H}}{ }^{+}\right)$is close to unity in $100 \mathrm{wt} \% \mathrm{H}_{3} \mathrm{PO}_{4}$, indicating a predominating Grotthuss type conduction. At lower acid concentrations, the higher water content promotes the acid dissociation and results in increased conductivity as well as contribution from the vehicular charge transport. At concentrations higher than $100 \mathrm{wt} \%$ $\mathrm{H}_{3} \mathrm{PO}_{4}$, on the other hand, the acid condensation leads to formation of pyro- and higher polymeric acids, which increase the contribution of the vehicular mechanism due to the addition of charge carrier in the system (e.g $\mathrm{H}_{2} \mathrm{P}_{2} \mathrm{O}_{7}^{2-}$ and $\mathrm{H}_{3} \mathrm{P}_{3} \mathrm{O}_{10}^{2-}$ ).

The practical implication of the contribution from the vehicular transport is the development of phosphoric acid concentration gradients between the anode and cathode side during fuel cell operation. Ultimately, this leads to severe acid redistribution within the membrane-electrode assembly and may be a trigger for acid loss, which has been identified as one of the most critical degradation modes. As first identified by Yu et al., ${ }^{19}$ the acid loss increases with increasing operational temperature and seems more severe at higher current loads. This was confirmed by Wannek et al., ${ }^{20}$ who observed the phosphoric acid accumulation in the gas diffusion electrodes after operation at different conditions. The acid-redistribution has more recently been monitored using in-operando imaging techniques. ${ }^{21-23} \mathrm{It}$ has been confirmed that the acid redistribution is of electrochemical origin and becomes more significant when a current load is applied. ${ }^{22}$ At temperatures above $160^{\circ} \mathrm{C}$ and current loads higher than $200 \mathrm{~mA}$ $\mathrm{cm}^{-2}$, the acid may even penetrate through the catalyst and gas diffusion layers of the anode side. ${ }^{23}$ 


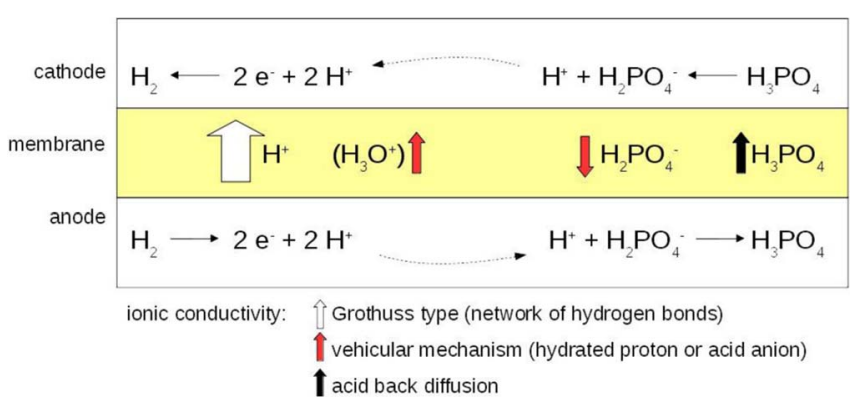

Figure 1. Schematic diagram of the chemical reactions and transport processes in a phosphoric acid doped polybenzimidazole membrane of the hydrogen pump mode.

In order to take a step further toward a quantitative understanding of the acid re-distribution in phosphoric acid doped $m$-PBI membranes, a method for integrating microelectrodes in the membrane was recently developed. ${ }^{24}$ The cell configuration makes it possible for a direct measurement of the ohmic response through different layers of the membrane, which is an indicator of the acid content change upon passage of an electrical current. In this way an in situ monitoring of the acid transport through the membrane layers is achieved, from which the transference number and diffusion coefficient of phosphoric acid can be determined at varied current densities, temperatures, and atmospheric water activities. Compared to the bulk phosphoric acid, ${ }^{18}$ the presence of a dense polymer phase and its acid-base interaction are studied with regards to the proton conductivity mechanism as well as the back diffusion of the acid molecules.

The principal experimental setup is a hydrogen pump cell where protons are generated at the anode side and reduced at the cathode side. A major difference from the fuel cell mode is that the hydrogen pump cell can operate under water free conditions, allowing for a study on dry state membrane systems at elevated temperatures of $160^{\circ} \mathrm{C}$ to $200^{\circ} \mathrm{C}$. Otherwise the presence of water shifts the acid dissociation toward ionic charge carriers:

$$
\mathrm{H}_{3} \mathrm{PO}_{4}+\mathrm{H}_{2} \mathrm{O} \leftrightharpoons \mathrm{H}_{2} \mathrm{PO}_{4}^{-}+\mathrm{H}_{3} \mathrm{O}^{+}
$$

which has impacts on the conductivity ${ }^{25-27}$ as well as the hydrogen pumping performance. ${ }^{28}$

\section{Modeling Hypothesis and Assumptions}

Model hypothesis.-As a working hypothesis, the focus for the vehicular charge transport is on the acid cycle at the right hand side of Figure 1. Under humidified atmosphere, there are mainly two types of species that are considered to contribute to the vehicular conduction of charges: the hydrated protons (hydronium ions) and the phosphoric acid anions. The presence of basic polymers promotes the acid dissociation, however, by formation of immobilized polymeric cations. The vehicular mechanism of hydronium ions requires a certain amount of mobile water molecules to be present in the membrane phase. In a typical HT-PEMFC working conditions, the relative humidity of the air stream is very low. At an air stoichiometry of 2 and temperature of $160^{\circ} \mathrm{C}$, the generated water in the air stream counts to an atmospheric relative humidity of ca. $3 \%$. Melchior et al. ${ }^{29}$ measured the hydration isotherm of the phosphoric acid and benzimidazole mixture in a molar ratio of 3, corresponding to an acid doping level of about $6 \mathrm{~mol} \mathrm{H}_{3} \mathrm{PO}_{4}$ per repeat unit of PBI. According to the isotherm, an atmospheric relative humidity of $3 \%$ at $160^{\circ} \mathrm{C}$ would result in a water uptake of the mixture that approximately corresponds to an acid concentration of $103 \mathrm{wt} \%$, i.e. little free water exists in the acid doped PBI membranes. In addition, the parasitic movement of the water molecules through the membrane, if any, gives very limited contribution to the ohmic resistance changes measured in the present study, compared with that of the phosphoric acid. It is therefore, for the sake of simplicity, that

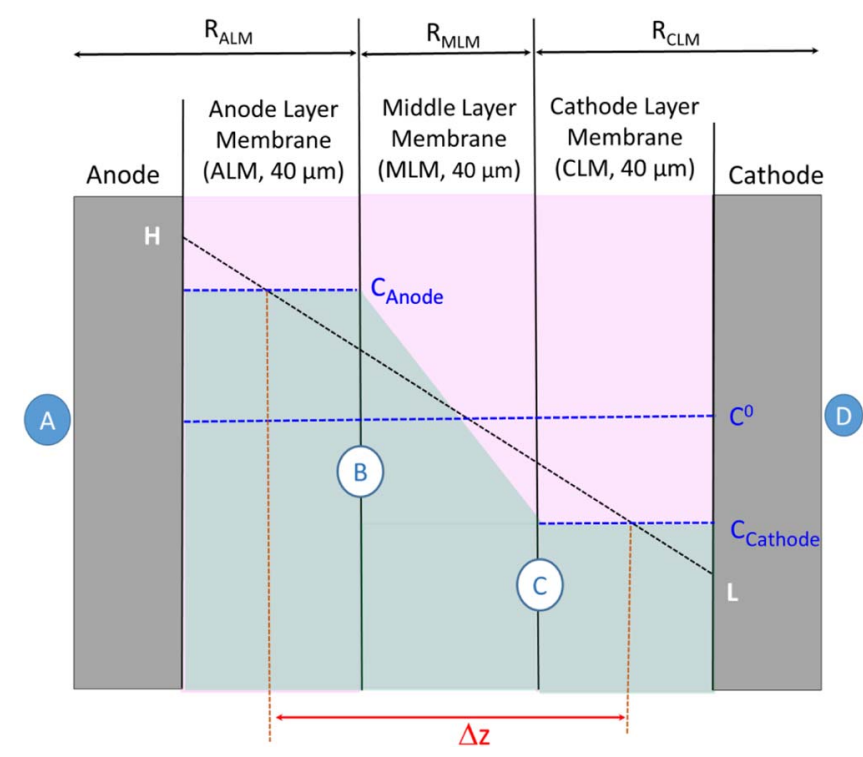

Figure 2. Sketch of the layered membrane cell, reference electrode configuration and the acid concentration profile. A and $\mathrm{D}$ are gas diffusion electrodes and $\mathrm{B}$ and $\mathrm{C}$ are reference electrodes. $\mathrm{R}_{\mathrm{MLM}}$ is the measured resistance across the middle layer membrane (MLM) while $R_{A L M}$ and $R_{C L M}$ are the measured resistances of the anode layer membrane (ALM) and the cathode layer membrane (CLM), respectively, including the electrode layer. $\mathrm{C}^{0}$ is the initial acid concentration through the three layer membrane. The black dashed line HL indicates the linear acid concentration gradient developed when a steady state between migration and diffusion is reached. The light blue profile is the model assumption where the anode $\left(\mathrm{C}_{\text {Anode }}\right)$ and cathode $\left(\mathrm{C}_{\text {Cathode }}\right)$ acid concentration are an average through the ALM and CLM, respectively, which drives the back diffusion across a distance of $\Delta z$.

only the vehicular mechanism via acid anions, no cations including hydronium ions $\left(\mathrm{H}_{3} \mathrm{O}^{+}\right)$, is considered in the model.

The acid anions are electrochemically migrating toward the anode, recombining with protons and generating an excess of phosphoric acid at the anode. The acid concentration gradient in turn gives rise to a diffusion flux back to the cathode side. The change of phosphoric acid concentration at anode and cathode side is determined by two processes: acid anion migration $J_{\text {Migration }}$ and acid back diffusion $J_{\text {Diffusion }}$ (Equation 2).

$$
\frac{\mathrm{dC}_{\mathrm{H}_{3} \mathrm{PO}_{4}}}{\mathrm{dt}} \cdot \mathrm{V}=\mathrm{J}_{\text {Migration }}-\mathrm{J}_{\text {Diffusion }}
$$

In Equation 2, $V$ is the reference volume of the cathode side and anode side (see Figure 2). The value is calculated from the geometric cell active area times the cathode/anode side membrane thickness. The anion migration can be understood as part of the net current flux which is described by Faraday's Law. The anion transference number $\mathrm{t}_{\mathrm{H}_{2} \mathrm{PO}_{4}^{-}}$in Equation 3 defines the fraction of the total current that is transported by these monovalent anions.

$$
\mathrm{J}_{\text {Migration }}=\frac{\mathrm{i} \cdot \mathrm{t}_{\mathrm{H}_{2} P O_{4}^{-}}}{\mathrm{F}}
$$

The process of acid back diffusion can be described by Fick's Law. In Equation 4, $D$ is the effective diffusion coefficient of phosphoric acid in the polymer matrix, $\Delta z$ the back diffusion distance of acid molecules (see Figure 2) and $A$ is the cell geometric active area of $8.8 \times 10^{-4} \mathrm{~m}^{2}$.

$$
\mathrm{J}_{\text {Diffusion }}=\mathrm{D} \frac{\Delta \mathrm{C}_{\mathrm{H}_{3} \mathrm{PO}_{4}}}{\Delta \mathrm{Z}} A
$$

An average acid concentration in the anode and cathode layer membrane, $\mathrm{C}_{\text {anode }}$ and $\mathrm{C}_{\text {cathode, }}$ is obtained from the measured membrane resistance change using the calibration curves of the ionic conductivity and swollen volume versus the acid doping level. The concentration 
gradient is defined as the difference between $\mathrm{C}_{\text {anode }}$ and $\mathrm{C}_{\text {cathode }}$ across the thickness of the diffusing layer $\Delta z$, as to be further discussed below. The diffusion coefficient $D$ is obtained from the time dependent restoration of the specific ohmic resistance after the cell current is shut down. Since there is no current, Equation 2 is only affected by $J_{\text {Diffusion }}$ and is therefore solved numerically by the following two steps:

$$
\begin{gathered}
\mathrm{J}_{\text {Diffusion }}(\mathrm{t})=\mathrm{D} \frac{\Delta \mathrm{C}_{\mathrm{H}_{3} \mathrm{PO}_{4}}(t)}{\Delta \mathrm{z}} A \\
\Delta \mathrm{C}_{\mathrm{H}_{3} \mathrm{PO}_{4}}(t+1)=\Delta \mathrm{C}_{\mathrm{H}_{3} \mathrm{PO}_{4}}(t)-2 \mathrm{~J}_{\text {Diffusion }}(\mathrm{t}) \mathrm{dt}
\end{gathered}
$$

The factor 2 for the flux $J_{\text {Diffusion }}$ comes from the fact that the acid concentration variations are subtracted from the anode and added to the cathode side. The time step of the numerical solution was $\mathrm{t}=1.0 \mathrm{~s}$. A variation of the time step by a factor of 3 did not change the results. Additionally, a baseline correction has been used because the calculated values of $\Delta \mathrm{C}$ approach but not reach zero as would be required by the theory.

Once the value of acid diffusion coefficient $D$ has been obtained from the time-resolved experiments, the acid migrated by electrochemical current can be calculated from the steady state condition: $\mathrm{dC}_{\mathrm{H}_{3} \mathrm{PO}_{4}} / d t=0$. Hence, the value of $\mathrm{t}_{\mathrm{H}_{2} \mathrm{PO}_{4}{ }^{-}}$can be readily obtained by Equation 7 .

$$
\begin{gathered}
\mathrm{D} \frac{\Delta \mathrm{C}_{\mathrm{H}_{3} \mathrm{PO}_{4}}}{\Delta \mathrm{z}} \mathrm{A}=\frac{\mathrm{i} \cdot \mathrm{t}_{\mathrm{H}_{2} P O_{4}^{-}}}{\mathrm{F}} \\
\mathrm{t}_{\mathrm{H}_{2} P O_{4}^{-}}=\mathrm{D} \frac{\Delta \mathrm{C}_{\mathrm{H}_{3} \mathrm{PO}_{4}}}{\Delta \mathrm{z}} \cdot \frac{\mathrm{A} \cdot \mathrm{F}}{\mathrm{i}}
\end{gathered}
$$

Cell Configuration, acid profile and model assumptions.-A schematic cross-sectional drawing of the layered membrane is shown in Figure 2, where the embedded microelectrodes are indicated as B and C. Typical hydrogen pump polarization curves were previously reported, ${ }^{24}$ indicating that the measured cell area specific resistance was primarily from the membrane.

It is well known that the hydrogen oxidation reaction (HOR) and hydrogen evolution reactions (HER) on platinum based catalysts are electrochemically reversible in acidic media. In $0.1 \mathrm{M} \mathrm{HClO}_{4}$ the HOR and HER current densities on rotating disc electrodes are entirely limited by the hydrogen diffusion, meaning that the HOR/HER exchange current densities in the acid electrolyte are one or more orders of magnitude larger than the typical hydrogen diffusion limited current density. ${ }^{30}$ This has been confirmed by the negligible activation overpotential at both anode and cathode of a hydrogen pumping cell with either Nafion or acid doped polybenzimidazole based cells..$^{28,31,32}$ It is therefore that the measured potential $\left(\mathrm{E}_{\mathrm{AB}}\right.$ and $\left.\mathrm{E}_{\mathrm{CD}}\right)$ and resistance $\left(\mathrm{R}_{\mathrm{AB}}\right.$ and $\left.\mathrm{R}_{\mathrm{CD}}\right)$ are assumed to be owing to the anode layer membrane (ALM) and cathode layer membrane (CLM), respectively.

Other assumptions for derivation of model parameters are as follows. Firstly, the $\mathrm{Pt}$ wire merely acts as a point measuring the potential at the interface between membrane layers. Secondly, a change in the membrane resistance is only caused by the acid migration. The influence of migrating water is ignored. Third, the acid content in the membrane layers calculated from the measured resistance changes by EIS. The calibration data is given in the supplementary information in section S.1. The resulting concentrations are ascribed as average values to the respective membrane layers as illustrated in Figure 2.

The horizontal blue dashed line in Figure 2 indicates the initial acid content $\mathrm{C}^{0}$ through the complied membrane layers and the black dashed line HL indicates the developed linear acid concentration gradient when a steady state between migration and diffusion was reached. A constant acid concentration $\mathrm{C}_{\text {anode }}$ and $\mathrm{C}_{\text {cathode }}$ is assumed for the ALM and CLM layers through which the specific ohmic resistance was measured. The concentration gradient $\left(\mathrm{C}_{\text {anode }}-\mathrm{C}_{\text {cathode }}\right)$ is assumed the driving force of back diffusion across a distance of $\Delta z$. Thus, the resulting diffusion pathway $\Delta z$ for the model calculation is therefore $80 \mu \mathrm{m}$ instead of the thickness of the middle layer membrane of $40 \mu \mathrm{m}$. In other words, the diffusion pathway starts from the middle of ALM and ends in the middle of CLM.

\section{Experimental}

Membranes and electrodes.-The membranes were prepared by solution casting from $N, N$-dimethylacteamide using $m$-PBI with an inherent viscosity of $1.44 \mathrm{dl} \mathrm{g}^{-1}$ (measured using an Ubbelohde viscometer for a solution with a solid content of $500 \mathrm{mg} \mathrm{dl}^{-1}$ in $96 \%$ $\mathrm{H}_{2} \mathrm{SO}_{4}$ at $30^{\circ} \mathrm{C}$ ). The $m$-PBI was prepared as described in more detail elsewhere. ${ }^{33}$ After drying at $120^{\circ} \mathrm{C}$ the membranes were thoroughly washed in boiling water and further dried at $120^{\circ} \mathrm{C}$ under reduced pressure. The membranes were then equilibrated in $85 \mathrm{wt} \% \mathrm{H}_{3} \mathrm{PO}_{4}$ (VWR Chemicals) at room temperature for two weeks. The acid doping levels were measured gravimetrically by assuming an acid to water molar ratio of about $1: 1$, i.e. about $85 \mathrm{wt} \% \mathrm{H}_{3} \mathrm{PO}_{4}$ in the membrane phase, as proposed previously. ${ }^{34}$ Membranes doped in acid of varied concentrations were prepared for calibration of the acid doping, volume swelling and conductivity. Membranes used in the present study were gravimetrically measured having an acid doping level of around 10 .

The catalyst layer was sprayed on top of a $3 \times 3 \mathrm{~cm}^{2}$ gas diffusion layer coated with a microporous layer (Freudenberg H23C2). Pt catalysts supported on carbon black (57\% Johnson Matthey HiSpec 9100) were dispersed in ethanol in an ultrasound bath for at least $1 \mathrm{~h}$ to get a well dispersed ink. The catalyst ink was then sprayed using a spray robot (Exacta-Coat from SONO-TEK Corporation) to reach a platinum loading of around $1 \mathrm{mg} \mathrm{cm}^{-2}$.

Cell assembling.-The cell was made of a compiled membrane consisting of 3 layers of about $40 \mu \mathrm{m}$ thickness each, as previously described. ${ }^{24}$ The outermost layers of the membranes were in direct contact with gas diffusion electrodes and referred to as the anode layer membrane (ALM) or cathode layer membrane (CLM). The membrane layer in between was called the middle layer membrane (MLM). Two reference electrodes were embedded between the ALM and MLM and between CLM and MLM (see Figure 2). Platinum wires of a diameter of $25 \mu \mathrm{m}$ plus $5 \mu \mathrm{m}$ polyimide insulation were used as the microelectrodes. Before embedded into the membrane layers, the insulation of the Pt wire tip was burned off and coated with a thin $m$-PBI layer, to provide a seamless integration of the wire between the two membrane interfaces. A polysulfone layer with an opening for the electrode active area of $8.8 \mathrm{~cm}^{2}$ was placed between the membrane and gas diffusion electrode for reinforcing the membrane. The layered membrane and Pt wire were positioned between two aluminum end plates with heating elements and current collectors. Clamping was done by giving a torque of $1 \mathrm{Nm}$ to the four $8 \mathrm{~mm}$ nuts and bolts located at the end corners of the endplates without previous hot-pressing of the membrane electrode assembly (MEA). Once assembled, the pretruding $25 \mu \mathrm{m} \mathrm{Pt}$ wire was welded to a thicker and sturdier Pt wire, which was connected to a cable plug for connection to Potentiostat electrodes.

Cell operation.-The hydrogen gas to both anode and cathode sides was supplied at a constant volumetric flow rate of

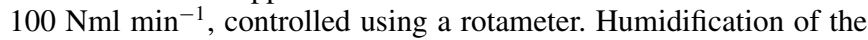
gas stream was done via an inhouse steel bolt evaporator connected directly to the cell housing gas inlet to eliminate cold spots where condensation of water may occur. The temperature setpoint for the evaporator was always set to the same value as the operation temperature of the hydrogen pump cell. Water was provided via a low flow infusion pump (Shimadzu LC-20AD) and mixed with the hydrogen gas inside the steel bolt evaporator. The cell was operated at temperatures within a range of $160-200^{\circ} \mathrm{C}$ and steam partial pressures $\left(P_{\mathrm{H}_{2} \mathrm{O}}\right)$ between 0-0.3 atm. In order to simplify the discussion, reference to each conditions will be coded as AAA-BBB, where AAA is the temperature in ${ }^{\circ} \mathrm{C}$ while $\mathrm{BBB}$ is the $P_{\mathrm{H}_{2} \mathrm{O}}$ in atm. For example, cell $160-0.17$ means a hydrogen pump cell operated at $160^{\circ} \mathrm{C}$ with a $P_{\mathrm{H}_{2} \mathrm{O}}$ 
of $0.17 \mathrm{~atm}$. Current was supplied to the cell via an external constant current tester (Elcanic) capable of providing current from 0.1 to $10 \mathrm{~A}$. Polarization curve recording of the hydrogen pump cell was done by stepwise increase of current within a range of 0 to $900 \mathrm{~mA} \mathrm{~cm} \mathrm{~cm}^{-2}$. A relaxation time of 5 minutes was applied at each current step. Electrochemical impedance spectroscopy (EIS) was done via a VersaSTAT potentiostat (Princeton Applied Research) in potentiostatic mode with an amplitude of $3 \mathrm{mV}$. EIS was recorded every 20-60 seconds after the current was turned on to measure the change of resistance at dry conditions. The time delay was shortened to every 2 seconds for the humidified experiments. The membrane resistance value was taken as $Z_{r e}$ at the high frequency intercept with the $Z_{i m}$ axis. The anode layer resistance was first monitored until a steady state was reached. After that, the current was switched off and another EIS spectrum was recorded in order to investigate the acid back diffusion profile. Once the relaxation of concentration was finished, the other layers were measured using the same procedure.

\section{Results and Discussion}

Effect of humidification.-The ohmic response of the phosphoric acid doped $m$-PBI membrane is known to depend strongly on the water activity, and the measurements were therefore carried out at different degrees of humidification. By feeding water into an evaporator and converging the steam flow with pre-heated air, the water partial pressure $P_{\mathrm{H}_{2} \mathrm{O}}$ was controlled at $0.1,0.17$ and 0.3 atm. The value of 0.17 atm was chosen by considering the practical humidity range of the cathodic air stream in fuel cells operating with an air stoichiometry $\lambda_{\text {air }}=2$. As shown in Figure $3 a$, the polarization curves for the hydrogen pumping cell showed a gradually decreasing slope with increasing degree of humidification. By switching from dry gas to $P_{\mathrm{H}_{2} \mathrm{O}}=0.1 \mathrm{~atm}$ the specific resistance of the cell was decreased from 0.27 to $0.19 \Omega \mathrm{cm}^{2}$. This resistance further decreased to 0.18 and $0.17 \Omega \mathrm{cm}^{2}$ at $P_{\mathrm{H}_{2} \mathrm{O}}=0.17 \mathrm{~atm}$ and $0.30 \mathrm{~atm}$, respectively. The slopes can be translated to ionic conductivities of $0.040,0.063,0.066$ and $0.070 \mathrm{~S} \mathrm{~cm}^{-1}$ at steam partial pressures of $0,0.1,0.17$ and 0.3 atm, respectively.

The constant membrane resistances are indicated by the points at zero current in Figures $3 \mathrm{~b}$ and $3 \mathrm{c}$. When a current was applied, a linear decrease of the anode layer membrane resistance $\left(\mathrm{R}_{\mathrm{ALM}}\right)$ was clearly observed while a steady increase in the cathode layer membrane resistance $\left(\mathrm{R}_{\mathrm{CLM}}\right)$ was observed as the current density was increased. For the cell operating with dry hydrogen, however, a plateau was observed for the increasing $R_{\text {CLM }}$ at current densities above $400 \mathrm{~mA} \mathrm{~cm}^{-2}$, which might be connected to the acid redistribution behavior within the catalyst layer at higher current densities and the limiting acid back diffusion.

Effect of temperature.-Proton conduction is a thermally activated process, which implies that the ohmic resistance decreases with increasing temperature. It should be kept in mind that increasing the temperature also changes the concentration of the phosphoric acid due to loss of water, which makes this correlation more complex to approach. However, as shown in Figure $4 \mathrm{a}$, the slope of the polarization curve decreased as the cell temperature was increased from $160^{\circ} \mathrm{C}$ to $200^{\circ} \mathrm{C}$. The decline was more pronounced when the temperature was increased from $160^{\circ} \mathrm{C}$ to $180^{\circ} \mathrm{C}$. At temperatures above $180^{\circ} \mathrm{C}$ the conductivity increase levels off due to the loss of water. ${ }^{35,36}$ In order to suppress the acid condensation, the cells were operated under a steam partial pressure of $0.17 \mathrm{~atm}$.

As mentioned above the hydration isotherms from Melchior et al. ${ }^{29}$ revealed that the water uptake of phosphoric acid in contact with benzimidazole is significantly reduced. In other words, the presence of the basic component (benzimidazole) enhances the condensation of phosphoric acid at a given temperature and relative humidity. This makes the acid condensation more an issue for the HT-PEM fuel cells than for phosphoric acid fuel cells, leading to an increased fraction of pyrophosphoric acid. ${ }^{10}$ This gives a compelling argument that the increased charge carrier mobility brought by increased temperature
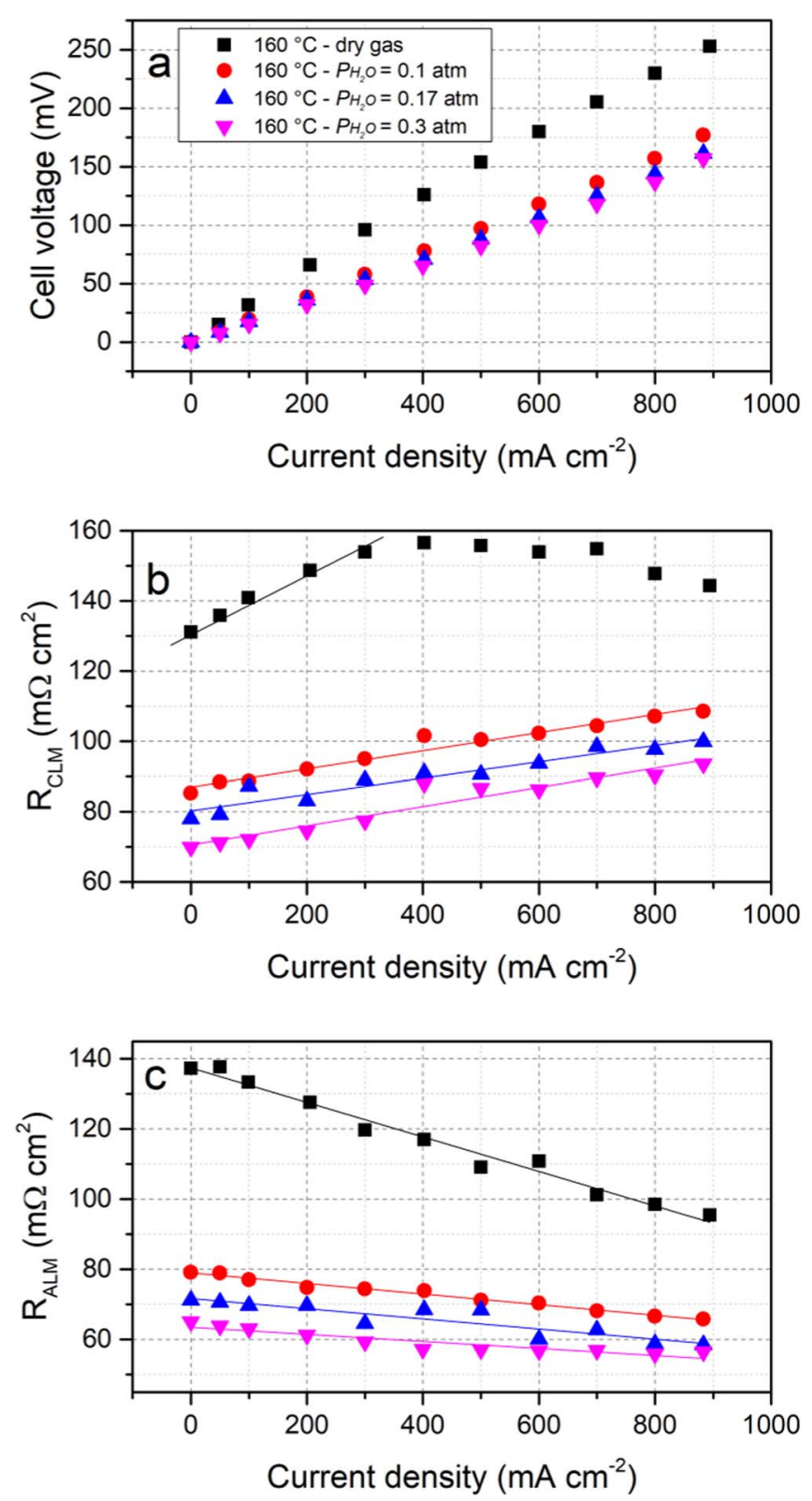

Figure 3. (a) Polarization curves of the whole cell, area specific resistance of the cathode layer membranes $\left(\mathrm{R}_{\mathrm{CLM}}, \mathrm{b}\right)$ and the anode layer membrane $\left(\mathrm{R}_{\mathrm{ALM}}\right.$, c) for a hydrogen pumping cell at $160^{\circ} \mathrm{C}$ at water partial pressures ranging from $0-0.3 \mathrm{~atm}$. The thickness of the each membrane layer was $40 \mu \mathrm{m}$.

triumphs over the adverse effect of acid condensation, at least under the present experimental conditions. As shown in Figure 4b, the decrease of the resistance at the anode side and corresponding increase at the cathode side were also observed as the temperature was increased up to $200^{\circ} \mathrm{C}$.

Modeling results for acid migration and back diffusion.-In order to obtain kinetic data on the membrane processes, a set of timeresolved measurements was designed. Herein, the $\mathrm{R}_{\mathrm{ALM}}$ and the $\mathrm{R}_{\mathrm{CLM}}$ series resistance were determined by recording the EIS over time at different conditions. A series of experiments were conducted at 200, 500 , and $800 \mathrm{~mA} \mathrm{~cm}^{-2}$ to be able to model the acid migration behavior at all operating conditions for three current density values. Figure 5 serves as one example of the time-resolved data for a cell operating under steam partial pressure of $0.3 \mathrm{~atm}$ at $160^{\circ} \mathrm{C}$ at a current density of $200 \mathrm{~mA} \mathrm{~cm}^{-2}$. The corresponding data for the cells operated at other temperatures and levels of humidification are provided 

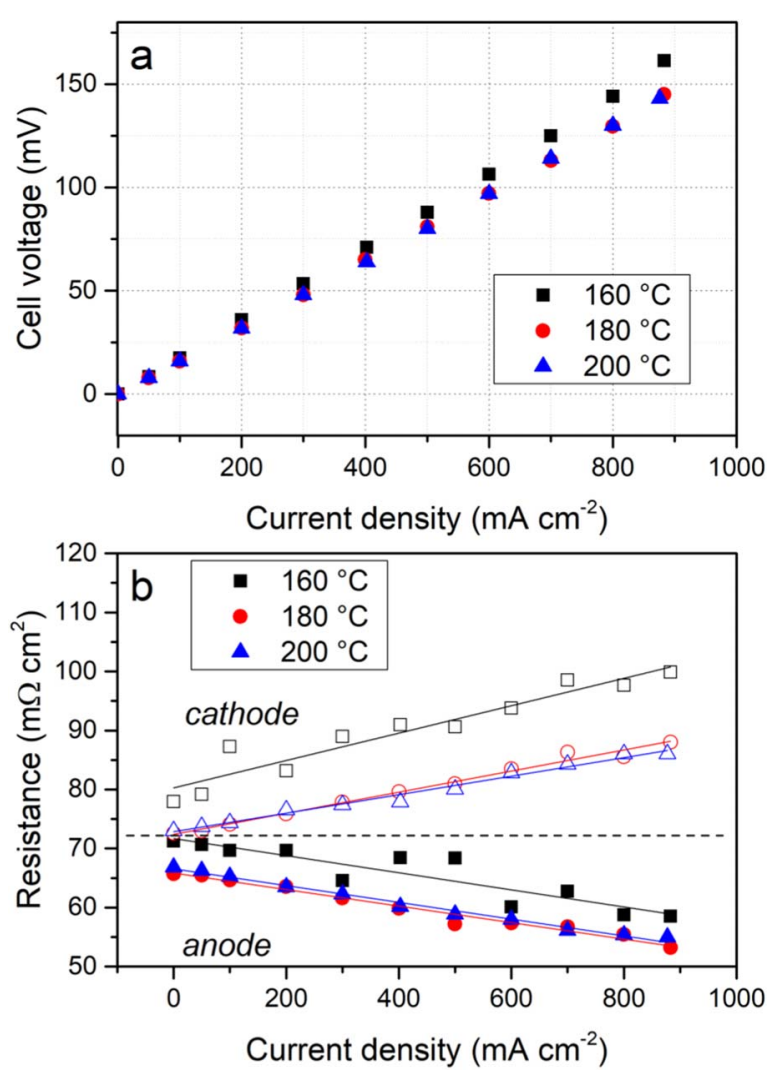

Figure 4. (a) Polarization curves of the hydrogen pump cells with a total membrane thickness of $120 \mu \mathrm{m}$ (40 $\mu \mathrm{m}$ each layer) at different temperatures and $P_{\mathrm{H}_{2} \mathrm{O}}=0.17 \mathrm{~atm}$. (b) The area specific resistance of the anode layer membrane $\left(\mathrm{R}_{\mathrm{ALM}}\right)$ is shown in solid symbols while that of the cathode layer membrane $\left(\mathrm{R}_{\mathrm{CLM}}\right)$ is shown in open symbols. Three temperatures were chosen as indicated in the figure.

in the supporting information (Figure $\mathrm{S} 2$ ). The initial $\mathrm{R}_{\mathrm{ALM}}$ and $\mathrm{R}_{\mathrm{CLM}}$ were 67 and $75 \mathrm{~m} \Omega \mathrm{cm}^{2}$, respectively, slightly different likely due to variation of the membrane thickness or the positioning of micro platinum reference electrodes.

When a polarization current was applied, the $\mathrm{R}_{\mathrm{ALM}}$ rapidly decreased, accompanied by an increase in the $R_{C L M}$. The ionic conductivity changes in the different layers of the membrane serve as

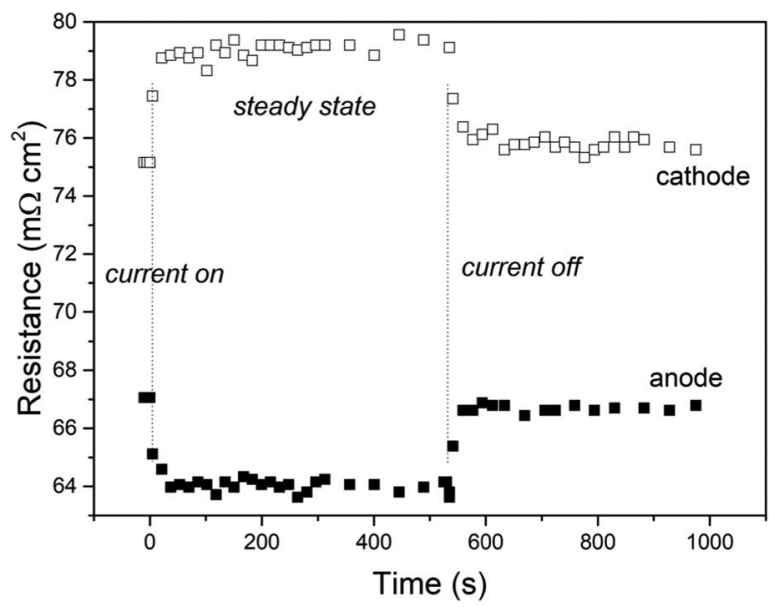

Figure 5. Illustration for the time evolution of specific resistances of the anode and cathode side membranes in a hydrogen pumping cell. The cell was operated at $160^{\circ} \mathrm{C}$ with humidified hydrogen of $P_{\mathrm{H}_{2} \mathrm{O}}=0.3 \mathrm{~atm}$. As indicated by the dashed line, the current was applied at 0 and stopped at $530 \mathrm{~s}$ at a set point current density of $200 \mathrm{~mA} \mathrm{~cm}^{-2}$.
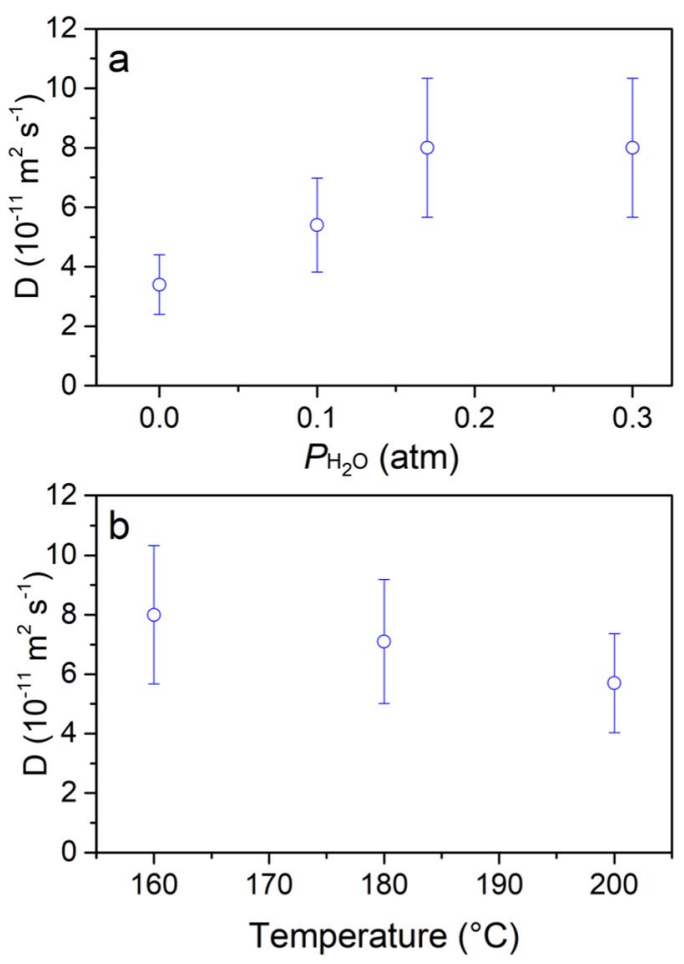

Figure 6. Chemical acid diffusion coefficient in phosphoric acid doped PBI membranes (a) at $160^{\circ} \mathrm{C}$ with different water partial pressures $P_{\mathrm{H}_{2} \mathrm{O}}$ and (b) at $P_{\mathrm{H}_{2} \mathrm{O}}=0.17 \mathrm{~atm}$ and different temperatures.

direct evidence for migration of acid anions, i.e. phosphoric acid accumulates at the anode side and depletes at the cathode side. These resistance changes reached a steady state when the electrochemical anion migration was balanced by the back diffusion of acid molecules, driven by the developed concentration gradient across the membrane. The current was then stopped and the cell was left for recording the time evolution of the resistance during the acid back diffusion, which resulted in the restoration of the initial resistance values of both the anode and cathode side membranes.

A set of PBI membranes of varied acid doping levels were calibrated in terms of volume swelling and ionic conductivity (see Supporting Information). The obtained correlation of the conductivity and volume swelling with the acid doping level is used for translation of the measured ohmic resistance of membranes into the molar acid concentration, in moles of phosphoric acid per liter $\left(\mathrm{mol} \mathrm{H}_{3} \mathrm{PO}_{4} \mathrm{~L}^{-1}\right)$ of the polymer membrane. The calibration curves are summarized in Figure $1 \mathrm{~S}$ of the supporting information and the fitting parameters are listed in Table I. Thus obtained acid concentration difference between ALM and CLM at different timescales during the "current off period" was first used to calculate the diffusion coefficient of the acid, from which the anion transference number was estimated from the "current on period" measurements.

The acid diffusion coefficient at each condition was obtained by averaging the fitted value at three current densities of 200, 500, and $800 \mathrm{~mA} \mathrm{~cm}^{-2}$, respectively. The exception is for hydrogen pump cell operated at $160^{\circ} \mathrm{C}$ under dry conditions, which only uses the data of $500 \mathrm{~mA} \mathrm{~cm}^{-2}$ due to data recording problems at the other two current densities.

Figure 6a compiles the value of the chemical acid diffusion coefficient $(D)$ as a function of the water partial pressure at a constant temperature of $160^{\circ} \mathrm{C}$. It is clearly seen that the $D$ increased when more water was added into the incoming gas stream. The value of $D$ was started at a value of $3.4 \times 10^{-11} \mathrm{~m}^{2} \mathrm{~s}^{-1}$ under dry conditions and then increased with the water partial pressure, maximizing at a value of $8 \times 10^{-11} \mathrm{~m}^{2} \mathrm{~s}^{-1}$ at $P_{\mathrm{H}_{2} \mathrm{O}}$ of $0.17 \mathrm{~atm}$. It has previously been pointed out in the literature that increase of water within the aqueous 


\begin{tabular}{|c|c|c|c|c|c|c|c|}
\hline$\left({ }^{\circ} \mathrm{C}\right)$ & $\begin{array}{l}P_{\mathrm{H}_{2} \mathrm{O}} \\
\text { (atm) }\end{array}$ & $a_{1}$ & $b_{1}$ & $\mathrm{R}^{2}$ & $a_{2}$ & $b_{2}$ & $\mathrm{R}^{2}$ \\
\hline 160 & 0 & 0.084 & 0.008 & 0.95 & 122.27 & 3.82 & 0.98 \\
\hline 160 & 0.3 & 0.066 & 0.007 & 0.975 & 99.22 & 2.59 & 0.98 \\
\hline 180 & 0.17 & 0.066 & 0.007 & 0.947 & 97.2 & 2.56 & 0.981 \\
\hline 200 & 0.17 & 0.067 & 0.007 & 0.944 & 97.48 & 2.47 & 0.98 \\
\hline
\end{tabular}

acid solution should give a lower viscosity to the system, resulting in a higher mobility of all particles within the system. ${ }^{37}$ In addition, the hydrolysis of higher polymeric phosphoric acid will also lower the viscosity of the overall phosphoric acid. In the presence of the polymer, the present measurement showed, however, that further addition of water into the gas stream from $P_{\mathrm{H}_{2} \mathrm{O}} 0.17$ to $0.30 \mathrm{~atm}$ did not seem to affect the value of $D$.

Figure $6 \mathrm{~b}$ compiles the value of $D$ as a function of temperature under a constant water partial pressure of $0.17 \mathrm{~atm}$. Apparently, the increase of temperature decreased the acid mobility as indicated with the decline of $D$. The value was decreased from 8 to $5.7 \times 10^{-11} \mathrm{~m}^{2} \mathrm{~s}^{-1}$ when the temperature was escalated from $160^{\circ} \mathrm{C}$ to $200^{\circ} \mathrm{C}$. It should be noted that the shown $D$ values at each condition are an average of replicates. The value of $D$ at these temperatures ranges from 4.3$8 \times 10^{-11} \mathrm{~m}^{2} \mathrm{~s}^{-1}$, which makes it unreliable to confer a decreasing trend at this point. In principle, an increase of temperature for a constant acid concentration should be followed by enhanced mobility. However, the opposing trend is shown, indicating that this effect is diminished by the acid condensation reaction. The diffusion coefficients for both conditions shown in Figures $6 \mathrm{a}$ and $6 \mathrm{~b}$ all fell within the same order of magnitude, which was $10^{-11} \mathrm{~m}^{2} \mathrm{~s}^{-1}$. It should be remarked that the diffusion discussed here occurs in form of net transport of mass in the presence of concentration gradient, i.e. the chemical diffusion coefficient. Using the Taylor dispersion technique Lang et al. ${ }^{38}$ measured the chemical diffusion coefficient of $\mathrm{H}_{3} \mathrm{PO}_{4}$ in aqueous solutions. For $85 \mathrm{wt} \% \mathrm{H}_{3} \mathrm{PO}_{4}$, the chemical diffusion coefficient was found to be $1.7 \times 10^{-10}$ at room temperature. Similar values were reported by Ruiz-Beviá et al. ${ }^{39}$ This value was increased to about $8.6 \times 10^{-10} \mathrm{~m}^{2} \mathrm{~s}^{-1}$ at $70^{\circ} \mathrm{C} .^{38}$ Taking the temperature effect into account, the diffusion coefficient of $\mathrm{H}_{3} \mathrm{PO}_{4}$ through the polymer phase obtained in the present study is at least an order of magnitude lower.

The values of the acid diffusion coefficient that has been obtained is then used to calculate the transference number of the monovalent anion $\left(\mathrm{t}_{\mathrm{H}_{2} \mathrm{PO}_{4}}\right)$ by using Equation 7. Table II summarizes the results of the acid transference number $\mathrm{t}_{\mathrm{H}_{2} \mathrm{PO}_{4}}$ as a function of water partial

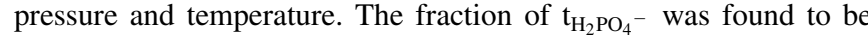
the lowest under dry conditions and slowly increasing as the water partial pressure was increased, following the trend exhibited by the

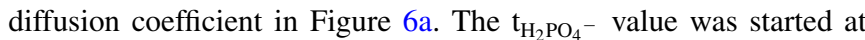
around 0.01 and increased to around 0.03 when the water partial pressure was at $0.17 \mathrm{~atm}$. The increasing amount of water within the phosphoric acid doped $m$-PBI system would result in a greater degree of pyrophosphoric acid hydrolysis, which promoted the formation of both $\mathrm{H}_{3} \mathrm{O}^{+}$and $\mathrm{H}_{2} \mathrm{PO}_{4}{ }^{-}$anions within the system and therefore increased the acid migration

As the temperature is increased under dry conditions, the phosphoric acid condenses to pyrophosphoric acid and higher oxoacid oligomers. The condensed phosphoric acid species show higher acidity than that of ortho-phosphoric acid. As a result, the condensed acid is able to protonate co-existing phosphorous oxoacid species, leading to formation of anions such as $\mathrm{H}_{2} \mathrm{P}_{2} \mathrm{O}_{7}^{2-}$ and $\mathrm{H}_{3} \mathrm{P}_{3} \mathrm{O}_{10}^{2-}$ as well as the cation $\mathrm{H}_{4} \mathrm{PO}_{4}^{+}$. When a current is applied between the electrodes, the anions tend to migrate toward the anode while cations migrate in the opposite direction. This means that, besides the back diffusion of acid toward the cathode, an additional driving force exists to oppose

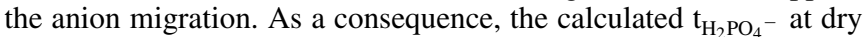
conditions is actually the net amount of acid due to anion migration subtracted by cation migration, if any.

A change of temperatures did not seem to have a strong effect on the acid transference numbers. As discussed in section Effect of temperature, the acid concentration did change very little for the conditions of the experiment. The lowest value is $97.2 \mathrm{wt} \%$ for $160-0.30$ and the highest is $100.5 \mathrm{wt} \%$ for $180-0.17$ and temperatures above. This means that virtually no free water molecules were present. The crossing of the $100 \%$ marked by a change in water vapor pressure indicates the involvement of the condensation processes affecting the $\mathrm{t}_{\mathrm{H}_{2} \mathrm{PO}_{4}}$ - variation. Nevertheless, it seems reasonable to assume that the electrolyte composition under real operating conditions is comparable to that of a working HT-PEMFC. This assumption is based firstly on the very low equilibrium water content of phosphoric acid solutions at these elevated temperatures. Secondly, a similar high concentration of $100 \mathrm{wt} \% \mathrm{H}_{3} \mathrm{PO}_{4}$ has been suggested by Maier et al. from the combination of synchroton X-ray radiography with EIS data. ${ }^{40}$

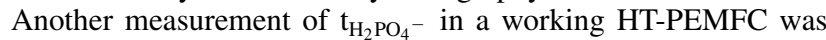
conducted by Eberhardt et al. ${ }^{23}$ They measured the amount of acid that ran-off into the GDL. Consequently, only very small values in the order of $10^{-3}$ to $10^{-5}$ were obtained. On the other hand, the

Table II. Calculated average acid concentrations, chemical diffusion coefficient $(D)$ and transference number of the monovalent anion $\left(t_{\mathrm{H}_{2}} \mathrm{PO}_{4}{ }^{-}\right)$ in a phosphoric acid doped $\boldsymbol{m}$-polybenzimidazole membrane.

\begin{tabular}{ccccc}
$\begin{array}{c}\text { Temp. } \\
\left({ }^{\circ} \mathrm{C}\right)\end{array}$ & $\begin{array}{c}P_{\mathrm{H}_{2} \mathrm{O}} \\
(\mathrm{atm})\end{array}$ & $\begin{array}{c}\text { Concentration of } \mathrm{H}_{3} \mathrm{PO}_{4} \\
(\mathrm{wt} \%)^{*}\end{array}$ & $\begin{array}{c}\text { Diffusion coefficient } D \\
\left(10^{-11} \mathrm{~m}^{2} \mathrm{~s}^{-1}\right)\end{array}$ & $\begin{array}{c}\text { Transference number } \\
\mathrm{t}_{\mathrm{H}_{2} \mathrm{PO}_{4}-}\end{array}$ \\
\hline 160 & 0.00 & - & $3.4( \pm 29 \%)$ & $0.01( \pm 29 \%)$ \\
160 & 0.10 & 100.55 & $5.4( \pm 30 \%)$ & $0.02( \pm 30 \%)$ \\
160 & 0.17 & 98.74 & $8.0( \pm 29 \%)$ & $0.04( \pm 29 \%)$ \\
160 & 0.30 & 97.16 & $8.0( \pm 29 \%)$ & $0.04( \pm 29 \%)$ \\
180 & 0.17 & 100.54 & $7.1( \pm 28 \%)$ & $0.02( \pm 28 \%)$ \\
200 & 0.17 & 100.58 & $5.7( \pm 28 \%)$ & $0.02( \pm 28 \%)$
\end{tabular}

${ }^{*}$ The phosphoric acid concentration under various humidities was estimated from the hydration isotherm by Melchior et al. ${ }^{18}$ 
phosphoric acid fuel cell (PAFC) community assumes that the anion transference number under its normal operating conditions is around $0.1 .^{41}$ It must be noted that the electrolyte in phosphoric acid fuel cells is contained in a ceramic matrix with a thickness about $200 \mu \mathrm{m},{ }^{42}$ with different mass transport properties than in a polymer membrane. The water uptake capabilities of the phosphoric acid is diminished as more benzimidazole is present within the system, causing phosphoric acid doped PBI to have a different acid composition in comparison to that of the PAFC. ${ }^{29}$ Also, the PAFC typically contains much more phosphoric acid than a HT-PEMFC. It seems reasonable that a fraction of $10 \%$ of the current involves the acid migration in PAFC while only $2 \%$ to $4 \%$ in HT-PEMFC. This may also correlate with the very low acid loss reported for HT-PEMFC operation. The effect of acid migration may also explain the observed increase in degradation of HT-PEMFC at very high current densities. ${ }^{43}$ The coupled effect of acid migration and back diffusion was also discussed for the operation of fuel cells with poly-perflourosulfonic acid membranes. ${ }^{44}$ In that case the very low diffusion coefficient of the acid is assumed to be responsible for the very poor performance.

\section{Conclusions}

Phosphoric acid is used as electrolyte in high temperature polymer electrolyte fuel cells and phosphoric acid fuel cells. It has been known that parasitic migration of acid species from the cathode to anode side occurs under normal operation conditions. This leads to an assumption that acid anions contributes to the overall charge transfer through the membrane. The current driven migration of acid anions gives rise to a concentration gradient, a driving force for back diffusion of acid from anode to cathode side. Both transport mechanisms are assessed by in situ measurement of the acid transport utilizing layered membranes with embedded platinum microelectrodes.

The phosphoric acid diffusion coefficient obtained in acid doped $m$-PBI membranes is in the order of $10^{-11} \mathrm{~m}^{2} \mathrm{~s}^{-1}$. This value is about at least one order of magnitude lower than that of aqueous phosphoric acid solutions, suggesting the effect of the dense polymer phase. From the anion transference number it can be concluded that under typical fuel cell operation conditions about $1 \%$ to $4 \%$ of the current is carried by the vehicular transference of acid anions and the rest via the Grothuss type or structure diffusion mechanism. The value of $4 \%$ of anion transference can be understood as the upper limit for the membrane systems, hinting a degradation mode in long term operation of HT-PEMFC.

\section{Acknowledgment}

Financial support from Innovation Fund Denmark (4M Centre) and ForskEL (SmartMEA) is acknowledged by the authors.

\section{ORCID}

Uwe Reimer (1D https://orcid.org/0000-0001-9776-8363

David Aili (1D https://orcid.org/0000-0002-3510-135X

Lars N. Cleemann (D https://orcid.org/0000-0001-5840-7477

Jens Oluf Jensen (D) https://orcid.org/0000-0002-2427-7763

Qingfeng Li (1) https://orcid.org/0000-0002-5460-055X

\section{References}

1. H. Janßen, L. Lüke, W. Lehnert, and D. Stolten, Int. J. Hydrogen Energy, 42, 11596 (2017).

2. Q. Li, D. Aili, H. Aage, H. Jens, and O. Jensen, High Temperature Polymer Electrolyte Membrane Fuel Cells, p. 2800, Springer International Publishing, Cham, (2016).
3. T. Søndergaard, L. N. Cleemann, H. Becker, D. Aili, T. Steenberg, H. A. Hjuler, L. Seerup, Q. Li, and J. O. Jensen, J. Power Sources, 342, 570 (2017).

4. J. S. Wainright, J.-T. Wang, D. Weng, R. F. Savinell, and M. Litt, J. Electrochem. Soc., 142, L121 (1995).

5. Q. Li, J. O. Jensen, R. F. Savinell, and N. J. Bjerrum, Prog. Polym. Sci., 34, 449 (2009).

6. J. A. Asensio, E. M. Sánchez, and P. Gómez-Romero, Chem. Soc. Rev., 39, 3210 (2010).

7. E. Quartarone and P. Mustarelli, Energy Environ. Sci., 5, 6436 (2012).

8. L. Xiao, H. Zhang, E. Scanlon, L. S. Ramanathan, E.-W. Choe, D. Rogers, T. Apple, and B. C. Benicewicz, Chem. Mater., 17, 5328 (2005).

9. R. A. Munson, J. Phys. Chem., 68, 3374 (1964).

10. C. Korte, F. Conti, J. Wackerl, and W. Lehnert, in High Temperature Polymer Electrolyte Membrane Fuel Cells: Approachs, Status and Perspectives, Q. Li, D. Aili, H. A. Hjuler, and J. O. Jensen, Editors, p. 169, Springer, Cham (2016).

11. L. Vilčiauskas, M. E. Tuckerman, G. Bester, S. J. Paddison, and K.-D. Kreuer, Nat. Chem., 4, 461 (2012).

12. N. Agmon, Chem. Phys. Lett., 244, 456 (1995)

13. N. Agmon, Isr. J. Chem., 39, 493 (1999).

14. T. Dippel, K. Kreuer, J. Lassegues, and D. Rodriguez, Solid State Ionics, 61, 41 (1993).

15. D. Weng, J. S. Wainright, U. Landau, and R. F. Savinell, J. Electrochem. Soc., 143, 1260 (1996).

16. M. K. Daletou, M. Geormezi, E. Vogli, G. a. Voyiatzis, and S. G. Neophytides, J. Mater. Chem. A, 2, 1117 (2014).

17. U. Reimer, J. Ehlert, H. Janßen, and W. Lehnert, Int. J. Hydrogen Energy, 41, 1837 (2016).

18. J.-P. Melchior, K.-D. Kreuer, and J. Maier, Phys. Chem. Chem. Phys., 19, 587 (2017).

19. S. Yu, L. Xiao, and B. C. Benicewicz, Fuel Cells, 8, 165 (2008).

20. C. Wannek, I. Konradi, J. Mergel, and W. Lehnert, Int. J. Hydrogen Energy, 34, 9479 (2009).

21. T. Arlt, W. Maier, C. Tötzke, C. Wannek, H. Markötter, F. Wieder, J. Banhart, W. Lehnert, and I. Manke, J. Power Sources, 246, 290 (2014).

22. S. H. Eberhardt, M. Toulec, F. Marone, M. Stampanoni, F. N. Buchi, and T. J. Schmidt, J. Electrochem. Soc., 162, F310 (2015).

23. S. H. Eberhardt, F. Marone, M. Stampanoni, F. N. Büchi, and T. J. Schmidt, J. Electrochem. Soc., 163, F842 (2016).

24. H. Becker, L. N. Cleemann, D. Aili, J. O. Jensen, and Q. Li, Electrochem. commun., 82, 21 (2017).

25. R. He, Q. Li, G. Xiao, and N. J. Bjerrum, J. Memb. Sci, 226, 169 (2003).

26. Y.-L. Ma, J. S. Wainright, M. H. Litt, and R. F. Savinell, J. Electrochem. Soc., 151 A8 (2004).

27. J. A. Asensio, S. Borros, and P. Gomez-Romero, J. Electrochem. Soc., 151, A304 (2004).

28. K. A. Perry, G. A. Eisman, and B. C. Benicewicz, J. Power Sources, 177, 478 (2008).

29. J.-P. Melchior, G. Majer, and K.-D. Kreuer, Phys. Chem. Chem. Phys., 19, 601 (2017).

30. W. Sheng, H. A. Gasteiger, and Y. Shao-Horn, J. Electrochem. Soc., 157, B1529 (2010).

31. S. J. Kim, B.-S. Lee, S. H. Ahn, J. Y. Han, H. Y. Park, S. H. Kim, S. J. Yoo, H.-J. Kim, E. Cho, D. Henkensmeier, S. W. Nam, T.-H. Lim, S.-K. Kim, W. Huh, and J. H. Jang, Int. J. Hydrogen Energy, 38, 14816 (2013).

32. Y. M. Hao, H. Nakajima, H. Yoshizumi, A. Inada, K. Sasaki, and K. Ito, Int. J. Hydrogen Energy, 41, 13879 (2016).

33. D. Aili, I. Javakhishvili, J. Han, K. Jankova, C. Pan, S. Hvilsted, J. O. Jensen, N. J. Bjerrum, and Q. Li, Macromol. Chem. Phys., 217, 1161 (2016).

34. Q. Li, R. He, R. W. Berg, H. A. Hjuler, and N. J. Bjerrum, Solid State Ionics, 168 177 (2004).

35. J. Lobato, P. Cañizares, M. A. Rodrigo, and J. J. Linares, Electrochim. Acta, 52, 3910 (2007).

36. D. Aili, L. N. Cleemann, Q. Li, J. O. Jensen, E. Christensen, and N. J. Bjerrum, J. Mater: Chem., 22, 5444 (2012).

37. X. Jiang, Y. Zhao, B. Hou, M. Zhang, and Y. Bao, J. Chem. Eng. Data, 56, 205 (2011).

38. S. Lang, T. J. Kazdal, F. Kühl, and M. J. Hampe, J. Chem. Thermodyn., 68, 75 (2014).

39. F. Ruiz-Beviá, J. Fernández-Sempere, and N. Boluda-Botella, AIChE J., 41, 185 (1995).

40. W. Maier, T. Arlt, K. Wippermann, C. Wannek, I. Manke, W. Lehnert, and D. Stolten, J. Electrochem. Soc., 159, F398 (2012).

41. T. Murahashi and J. Garche, Editor. Encycl. Electrochem. Power Sources, 564 (2009).

42. K. Mitsuda, T. Murahashi, M. Matsumoto, and K. Usami, J. Appl. Electrochem., 23 19 (1993).

43. U. Reimer, B. Schumacher, and W. Lehnert, J. Electrochem. Soc., 162, F153 (2014).

44. D. Aili, R. F. Savinell, J. O. Jensen, L. N. Cleemann, N. J. Bjerrum, and Q. Li, ChemElectroChem, 1, 1471 (2014). 